\title{
COMO EXPLORAR UM ARQUIVO?
}

\author{
Raúl Antelo \\ UFSC
}

RESUMO: A escritura é um dispositivo e a história da cultura é um incessante corpo-a-corpo com outros dispositivos, particularmente, a linguagem. 0 sentido se produz onde 0 ser vivo, ao encontrar a linguagem e pondo-se nela em jogo, exibe, em um gesto, a própria irredutibilidade a ela. A proposta é percorrer um arquivo para resgatar as potencialidades da linguagem e assim reinventar a leitura até mesmo dos textos mais canônicos.

PALAVRAS-CHAVE: Arquivo. Modernidade. Sentidos.

\section{HOW TO EXPLORE AN ARCHIVE?}

ABSTRACT: Writing is an apparatus and the history of culture is an incessant friction with other dispositives, particularly, the language. Meaning is produced where the living being, when the being finds the language and is implicated in it, shows, in a gesture, its own irreducibility to the language. The objective is to proceed through an archive in order to rescue the potentialities of language and thus reinvent the reading even of the most canonical texts.

KEYWORDS: Archive. Modernity. Meanings.

Raúl Antelo é professor titular de Literatura Brasileira no Departamento de Língua e Literatura Vernáculas e professor do Programa de Pós-Graduação em Literatura da Universidade Federal de Santa Catarina. Pesquisador CNPq. 


\section{COMO EXPLORAR UM ARQUIVO?}

Raúl Antelo

Em "O autor como gesto", um dos ensaios de Profanações, Giorgio Agamben nos diz que o sujeito não é algo que possa ser alcançado objetivamente como uma realidade substancial presente em algum lugar; pelo contrário, ele é o que resulta do encontro e do corpo-a-corpo com os dispositivos em que ele foi inserido. Isso porque também a escritura é um dispositivo, e a história da cultura talvez não seja nada além de um incessante corpo-a-corpo com os dispositivos que os homens produziram, basicamente um, a linguagem. E assim como o autor deve continuar inexpresso na obra e, no entanto, precisamente desse modo, ele testemunha a própria presença irredutivel, também a subjetividade se mostra e resiste, com mais força, no ponto em que os dispositivos a capturam e põem em jogo. Uma subjetividade produz-se onde o ser vivo, ao encontrar a linguagem e pondo-se nela em jogo, sem reservas, exibe, em um gesto, a própria irredutibilidade a ela. Por isso, para apontar as potencialidades da linguagem, gostaria de propor o recuo a uma experiência iniciática. Um dos poemas de Azul, o livro de Rubén Darío, pioneiro da modernidade latino-americana, lido na adolescência, permite-me refletir de que modo a prática do arquivo pode nos auxiliar a reinventar os textos canônicos mais surrados e triviais. Diz o poema:

Vi ontem por uma janela um cesto cheio de lilases e de rosas pálidas, sobre um tripé. Por fundo tinha uma dessas cortinas amarelas e opulentas, que fazem pensar nos mantos dos príncipes orientais. As lilases recém cortadas ressaltavam com sua linda cor aprazível, junto às pétalas esponjadas das rosas cor-de-chá. Junto ao cesto, em uma copa de laca ornada com íbis de ouro incrustado, incitavam à gula maçãs frescas, meio coloradas, com a penugem da fruta nova e a saborosa carne inchada que toca o desejo; peras douradas e apetitosas, que davam indícios de serem todas suco, e como esperando a faca de prata que devia recortar a polpa cheia de calda; e um ramalhete de uvas negras, até com a poeira cinzenta dos racimos acabados de arrancar da vinha.

Aproximei-me, vi-o tudo de perto. As lilases e as rosas eram de cera, as maçãs e as peras de mármore pintado, e as uvas de cristal.

Natureza morta! ${ }^{1}$

1 He visto ayer por una ventana un tiesto lleno de lilas y de rosas pálidas, sobre un trípode. Por fondo tenía uno de esos cortinajes amarillos y opulentos, que hacen pensar en los mantos de 
Darío é o primeiro poeta latino-americano a ensaiar uma paradoxal arte de massas. É de massas porque se trata de uma poética democratizante. Mas é, ao mesmo tempo, aristocrática porque trata de uma arte elaborada, ou seja, que lida com a criação e a reconfiguração das formas e valores. O dado novo em Darío não é nunca um simples dado emergente, algo original, um achado, mas o produto de uma complexa e artificial máquina de ficção totalmente contingente; e o que de fato se constrói desse modo é o próprio processo de leitura. Darío cria um modo de ler. Sua vontade direcionada à significação transforma a própria representação em uma máquina significante que cria, eventualmente, a ilusão da presença, mas para levar o sujeito na direção oposta à antiga escatologia. Darío nos diz que há "o moderno", só que ele é a defesa obscuramente vitoriosa de uma época crivada de abusos. Existe um líder, mas errático. Existe um messias, mas remoto. Existe um deus, mas vive disperso em agonia. Darío constrói assim um fabuloso cristal de inconsistência, visível pela transparência, como um aleph, através do gesto de suas princesas, sereias, heróis, mas também de toda a quinquilharia da modernização. O decisivo nele é a questão da distância, tanto mais contundente quanto mais próxima, obedecendo àquilo que Benjamin chamava de aura. O gesto é decisivo: "Aproximei-me, vi tudo de perto." Seus frutos são impossíveis naturezas mortas, mas estão vivos. Confunde o puro com o impuro, atraído que ficou pelo lixo industrial feito em série. $E$, nesse sentido, Darío é um artista do dinheiro, um cronista. Mas há também algo de divino nessa construção que é, na verdade, algo sagrado, que não pode ser tocado e não vai além de si próprio: o poeta moderno, também ele cindido, está, entretanto, articulado em torno do acaso, tal como, mais tarde, em Borges: "Darío e eu".

Com efeito, aparece em Darío o vazio da representação, o vazio da própria linguagem. Ele inaugura a glosa deshierarquizada, na qual outros textos

los príncipes orientales. Las lilas recién cortadas resaltaban con su lindo color apacible, junto a los pétalos esponjados de las rosas té.

Junto al tiesto, en una copa de laca ornada con ibis de oro incrustado, incitaban a la gula manzanas frescas, medio coloradas, con la pelusilla de la fruta nueva y la sabrosa carne hinchada que toca el deseo; peras doradas y apetitosas, que daban indicios de ser todas jugo, y como esperando el cuchillo de plata que debía rebanar la pulpa almibarada; y un ramillete de uvas negras, hasta con el polvillo ceniciento de los racimos acabados de arrancar de la viña. Acerquéme, vilo de cerca todo. Las lilas y las rosas eran de cera, las manzanas y las peras de mármol pintado, y las uvas de cristal.

¡Naturaleza muerta! 
aparecem restituídos à pura letra, como ecolalias. Recicla citações e referências, que assim adquirem valor de objets trouvés, e com elas compõe um arquivo literário, que é a própria matéria de uma autofiguração que precisa de testemunhas, os multitudinários e anônimos leitores do jornal. Walter Benjamin trabalhou nessa mesma linha e deparou-se, nas gravuras de Grandville, com a fantasia, ao mesmo tempo infantil e técnica, do moderno. Encontrou, em uma figuração de outros tempos, fusionando natureza e mundo mecânico, tanto a magia quanto a mercadoria do moderno. Darío conhecia a obra de Grandville e, no seu texto, leio uma definição de como entendermos hoje o arquivo literário:

\begin{abstract}
Grandville, el admirable dibujante que veía con tanta acuidad lo real, tenía una honda intuición de lo misterioso. Aquel gran obrero era un gran soñador; aquel artista, cuya lógica era inflexible, penetra en lo ideal y en lo raro, con la deducción unida a la fantasía. En sus comparaciones o correlaciones antropozoológicas fué un continuador de Fechsius y de Giovan Batista Dellaporta, cuya obra es posible que no conociera. Y quizá por pura coincidencia los dibujos del libro Della fisionomía dell'uomo, diríase que son seguidos, con el agregado de un ingenio moderno, en L'homme descend vers la brute, l'animal monte vers l'homme, en Têtes d'hommes et d'animaux comparées, y en otros estudios y hallazgos artísticos semejantes.
\end{abstract}

Darío sabia que Grandville tinha sido muito admirado por Poe. Cita-o em crônica para La Nación de julho de 1913. Além do mais, acreditava que Grandville, como Robert de Montesquiou, tinha conseguido decifrar hieróglifos. Entre esses enigmas, estão os correspondentes aos sonhos. Nas páginas de Montesquiou há uma única referência a eles, nesta frase: “... le prélude du cauchemar, il s'y enfonça, le dessinant -- devançant Odilon Redon dans l'empire du songe." É uma citação de Roseaux pensants de Montesquiou, que por sua vez é uma citação dos Pensamentos de Pascal: L'homme n'est qu'un roseau, le plus faible de la nature; mais c'est un roseau pensant. Ou seja, o homem é um junco, o mais fraco da natureza, mas é um junco pensante. E vejam que junco é outro nome para lilás ou siringa, com o qual retornamos à natureza morta. Por isso, para Darío, "Grandville, no hay que dudarlo, tenía la percepción íntima de 'lo que ven los ojos de sombra'."

Vamos então perscrutar o arquivo, não com olhos iluminados, olhos do Esclarecimento, mas com "ojos de sombra”, olhos de massa e ressaca. EscoIheria, para tanto, a imagem de um espaço, o Ateneu Hispano-americano de 
2 "Ateneos, Sociedades de artistas y de literatos, Escuelas de bellas artes, exposiciones de pintura y escultura, Universidades Populares, cuando logran nacer de las abnegaciones de algún pequeño grupo, arrastran vida precaria y casi siempre efímera, sin lograr nunca echar raíces hondas en esta tierra todavía impermeable. Son instituciones exóticas que nuestras clases dirigentes miran y no protegen y el pueblo en su total ignorancia de analfabeto contempla y no comprende." OLIVERA, Ricardo. Sinceridades. Ideas, Buenos Aires, a. I, n. 1, maio 1903, p. 6-9. O Ateneu Hispano-americano, versão plebeia do Ateneu que funcionava na galeria Au Bon Marché, a atual galeria Pacífico, era presidido, justamente, por Carlos Malagarriga, jurisconsulto e mentor de Macedonio Fernández, de quem se tornaria muito amigo, ao ponto deste introduzí-lo no pensamento de Bergson, de quem Malagarriga foi seu primeiro tradutor ao espanhol. Um dos discursos de colação de grau em Direito, em 1916, dá-nos a pauta do pensamento hispano-americano de Malagarriga. "Cabe disentir dizia- de los que creen que algún día toda la América formará un solo estado ó única anfictionía: puede discutirse si hay una ó varias Américas - de lo espiritual hablo - y aún si dentro de alguna de éstas, hay tanta igualdad de caracteres y tan parecida posibilidad de destinos como en apariencia se dibujan. Pero hay que aceptar de un modo terminante y rotundo, que pueblos como este nuestro, formados principalmente por elementos que vinieron y vienen, huyendo - consciente ó inconscientemente - del peso muerto de la tradición que en Europa les ahogaba, han de sentirse empujados, por la fuerza inicial de aquel primitivo impulso, hacia lo porvenir y no adormecidos en la rumia de lo que ya pasó. Por esto, por ser y por sentirnos argentinos, parece que fuéramos y nos sintiéramos dos veces jóvenes y por ello doblemente obligados á mostrarnos en este día optimistas y resueltamente orientados, no hacia lo que fué, sino hacia lo que nos aguarda." A composição do Ateneu Hispanoamericano era heterogênea. Seus vice-presidentes eram Eduardo López Bago e o diretor do Clube Espanhol, Rafael Escriñá; o secretario, Julián de la Cal, crítico do Diario Español; o tesoureiro Ibáñez, gerente do Banco de Castilla, e o bibliotecário era Juan Mas y Pí, redatorchefe de El Diario Español, amigo de Carriego, ligado a La Protesta, mas introdutor também do futurismo em 1909. Como vocais apareciam José Maria Salaverria, Martín Dedeu, Luis de Villalobos, J. Torrondell, que criaría as edições Tor no ano de 1916, o escritor e tradutor Juan Manuel Aguado de la Loma, Morales Navas, o dr. Criado, Antonio Herrero, Luis Méndez Calzada, José Parra y Julio del Romero. Pelo lado argentino, a junta diretiva era integrada por José León Suárez, chefe da Direção de Pecuária e catedrático da Faculdade de Direito; Joaquín V. González, reitor da Universidad de La Plata; Juan Carlos Delfino, vice-decano da Facultad de Derecho de Buenos Aires; o Dr. Cullen, médico notabilíssimo; Andrés Llamazares e Ernesto Sourrouille, presidente da Sociedade de Estudantes da Facultad de Derecho da UBA e antepassado do criador do plano Austral. Frequentava suas reuniões o músico Julián Aguirre. Cf. CAL, Julián de la. Confraternidad Hispano-americana. Mundo gráfico, Madrid, a. 2, n. 56, 20 nov. 1912. Aos 25 anos de sua fundação, sua biblioteca, "Doctor José León Suárez", cujo maior acervo era formado pelos volumes doados pela sra. Lía Damianovich de Suárez, viúva do inesquecível internacionalista, tem 10.000 obras seletas, às que se planejava adicionar as seções brasileira e uruguaia. (El Ateneo Ibero-Americano celebra sus bodas de plata. Caras y caretas, Buenos Aires, n. 2032, 11 set. 1937, p. 38).

${ }^{3}$ De fato, em primeiro de setembro de 1912 se inaugura, na Rua Rivadavia 1391, o Ateneu Hispano-Americano de Buenos Aires. Rubén Darío, acompanhado do Ministro de Instrução Pública, doutor Juan María Garro, e de outras pessoas, concorreu à cerimônia inaugural. Depois de ser apresentado pelo doutor Joaquín V. González e de uma alocução do escritor espanhol Vicente Blasco Ibañez, Rubén Darío recitou seu poema "Español" em homenagem aos fundadores do Ateneu, cujo tom, aludindo a "la grieta", recorda Manuel Machado: "Yo siempre fui, por alma y por cabeza, /español de conciencia, obra y deseo./ Y yo nada concibo y nada veo/ sino español por mi naturaleza./ Con la España que acaba y la que empieza, 
Nesse mesmo espaço, quatro anos mais tarde, o poeta Vicente Huidobro imporia o conceito de criacionismo, reivindicando que "la primera condición del poeta es crear, la segunda crear y la tercera crear", tese adamítica que não chegou a convencer o sociólogo José Ingenieros, ali presente, que lhe manifestou que "su sueño de una poesía inventada en cada una de sus partes por los poetas me parece irrealizable, aunque usted lo haya expuesto en forma muy clara e incluso muy científica." ${ }^{4}$ Surge então a disputa entre criacionismo, de um lado, e transculturação ou hibridação, do outro. Criação ou curadoria, nos diria Boris Groys, são os dois vetores do poder da arte. Mas Baudelaire já o tinha dito em Meu coração desnudado: "de la vaporisation et de la centralisation du Moi. Tout est là." Há, de fato, um sentido do poema que remete ilusoriamente ao mundo e há um outro sentido que só se projeta, alegoricamente, à própria ausência de fundamento da experiência mundana.

\footnotetext{
/canto y auguro, profetizo y creo, /pues Hércules allí fue como Orfeo:/ ser español es timbre de nobleza./ Y español soy por la lengua divina, /por voluntad de mi sentir vibrante:/ alma de rosa en corazón de encina./ Quiero ser quien anuncia y adivina, /que viene de la pampa y la montaña: / eco de raza, aliento que culmina / con dos pueblos que dicen: ¡Viva España!/ ¡Y viva la República Argentina!" Narra uma testemunha que Darío "complacido asistió a una comida que le ofreció Enrique García Velloso, la que fue una fiesta muy de su agrado, pues no hubo discursos; en cambio, charla amena, amable, ingeniosa. He aquí la nómina de los comensales: Mariano de Vedia, José Luis Murature, Jorge Drago Mitre, Fernando Alvarez, Manuel Mayol, Justo López de Gomara, Julio Piquet, Rodolfo de Puga, Tito L. Arata, Carlos Vega Belgrano, Antonino Lamberti, Alfredo Duhau, Alberto Ghiraldo, Julio Castellanos, Alfredo Guido, Luis Berisso, José María Salavarría, Juan Carlos Alonso, Ernesto Vergara Biedma, Enrique Hurtado y Arias, Emilio Becher, Martín Reibel, José Ojeda, Alfredo Bastos, Florencio Parravicini, Felipe Sassone, Ismael Cortina, Carlos Malagarriga y Alberto Núñez." Cf. URQUIZA, Juan José de. La amistad de Rubén Darío y Enrique García Velloso. Santiago de Chile: Atenea, s.d., p. 449-450.

${ }^{4}$ HUIDOBRO, Vicente. Obra selecta. Selección, prólogo, notas, cronología y bibliografía de Luis Navarrete Orta. Caracas: Biblioteca Ayacucho, 1989, p. 307.

${ }^{5}$ BAUDELAIRE, Charles. Oeuvres Complètes. Ed. Claude Pichois. t. I. Paris: Gallimard, 1976, p. 676.
} 


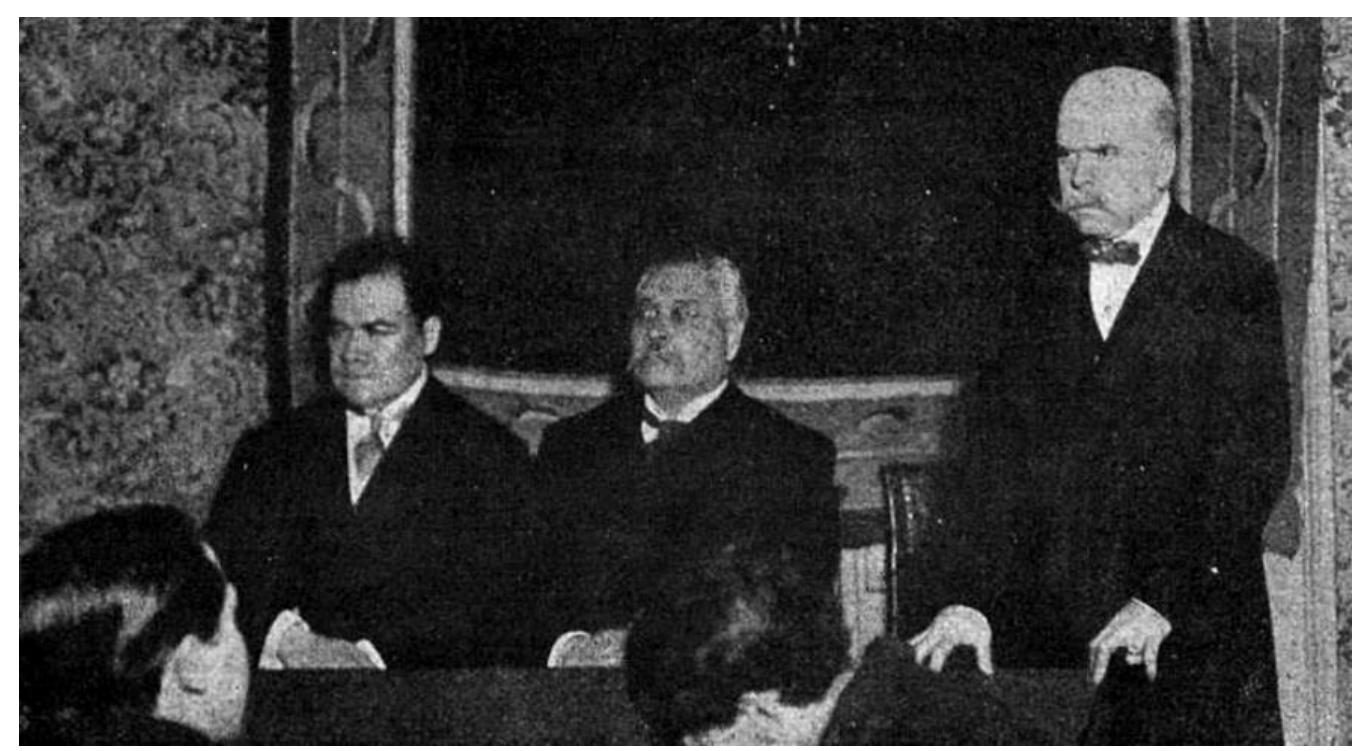

IMAGEM 1 - EN EL ATENEO HISPANO-AMERICANO

La mesa directiva del Ateneo Hispano-Americano, mientras hacía uso de la palabra el doctor Carlos Malagarriga.

"Caras y caretas", Buenos Aires, N 727, 7 set. 1912

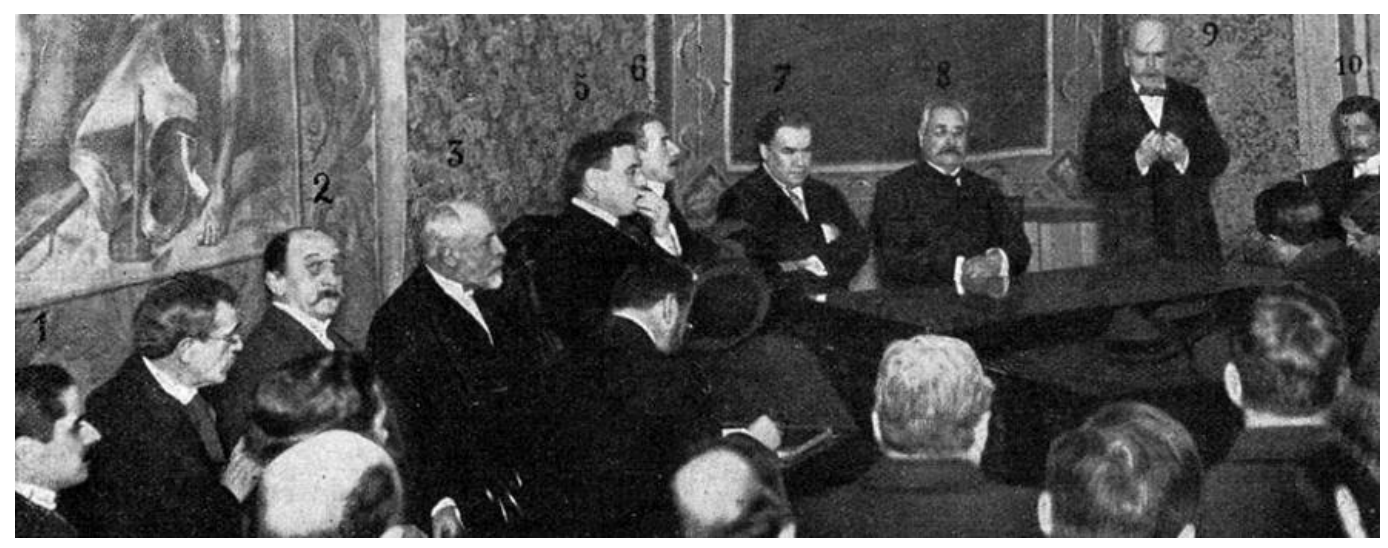

IMAGEM 2 - ACTO INAUGURAL DEL ATENEO HISPANO-AMERICANO, EN BUENOS AIRES

1. Dr.José Morales Navas, vocal de la Junta directiva. -2. D. Eduardo López Bago, vicepresidente. -3. D. Rafael Escriñá, vicepresidente. -4. D. Julián de la Cal, secretario. -5. Dr. José León Suárez, vicepresidente. -6. Dr. Norberto Piñero, decano de la Facultad de Filosofia y Letras. -7. Rubén Darío. 8. Dr. Garro, Instrucción Pública. -9. D. Carlos Malagarriga, presidente. -10. Dr. Andrés Llamares, secretario del ministro de Agricultura.

À época da morte de Darío, em 1916, quando Benjamin começava a pensar no drama alegórico, Simmel estipulava também, a partir de Rembrandt, uma diferença crucial entre o criativo e o configurativo. Argumentava que, para além do próprio trabalho, não existe nenhuma obra que 
não seja simultaneamente configuradora e criadora. Darío foi um poeta da configuração, da montagem. No caso de Prosas profanas, por exemplo, as mais bem-sucedidas seriam justamente as reconfigurações do grego, as festas galantes, as novas versões de textos passados, os escólios à arte em geral, porque, como já dizia "Ecce Homo", o poema do spleen, "hoy las viejas creaciones / de las antiguas eras, / sirven en los salones / para muestras de torsos y caderas." 6

Pois bem, nesse mesmo ano, começava a circular, em Buenos Aires, a Plus Ultra, uma revista mensal de prosas profanas que buscava o global em um momento no qual o próprio mundo se transformava na revista ilustrada, pela qual circulavam todas as outras imagens. ${ }^{7}$ A revista surge exatamente quando Rubén Darío morre. No seu segundo número, precisamente em homenagem ao poeta, seu diretor, o artista plástico Juan Carlos Alonso (1886-1945), oferece-nos uma cabeça de Darío (imagem 3), que prefigura a posterior disputa sobre o cérebro dele ou a simples simbolização conservadora do poeta, herói cívico da Nicarágua.

${ }^{6}$ DARIO, Rubén. Poesia. Prólogo Ángel Rama. Ed. Ernesto Mejía Sánchez. Caracas: Ayacucho, 1986, p. 75

7 SLOTERDIJK, Peter. La época (criminal) de lo monstruoso. In: Sin salvación. Tras las huellas de Heidegger. Trad. J. Chamorro Mielke. Madrid: Akal, 2011, p. 245. Para seu estudo, consultar WECHSLER, Diana B. Revista Plus Ultra: un catálogo del gusto artístico de los años veinte en Buenos Aires. Estudio e Investigaciones, Buenos Aires, Instituto de Teoría e Historia de las Artes "Julio E. Payró", Facultad de Filosofía y Letras, Universidad de Buenos Aires, n. 4, 1991, p. 199-209; MANGONE, Carlos. Plus Ultra: entre el pastel y la gouache. In: MONTALDO, Graciela (Ed.). Literatura argentina del siglo XX. Yrigoyen entre Borges y Arlt. Buenos Aires, 1989, p. 104-5; CAPRARA, Susana; FERRANDINI, Luis. Las revistas y las artes gráficas: Plus Ultra. Boletín del Instituto de Historia del Arte Argentino y Americano, La Plata, v. 10, n. 8 , Instituto de Historia del Arte Argentino y Americano, Facultad de Bellas Artes, UNLP, 1988, p. 53-61; ORLANDO, Diego A. Plus Ultra: entre la obnubilación aristocrática y la arrogancia despótica. El Matadero. Revista crítica de literatura argentina, Buenos Aires, segunda época, n. 4, Corregidor, mar. 2006, p. 29-54. 


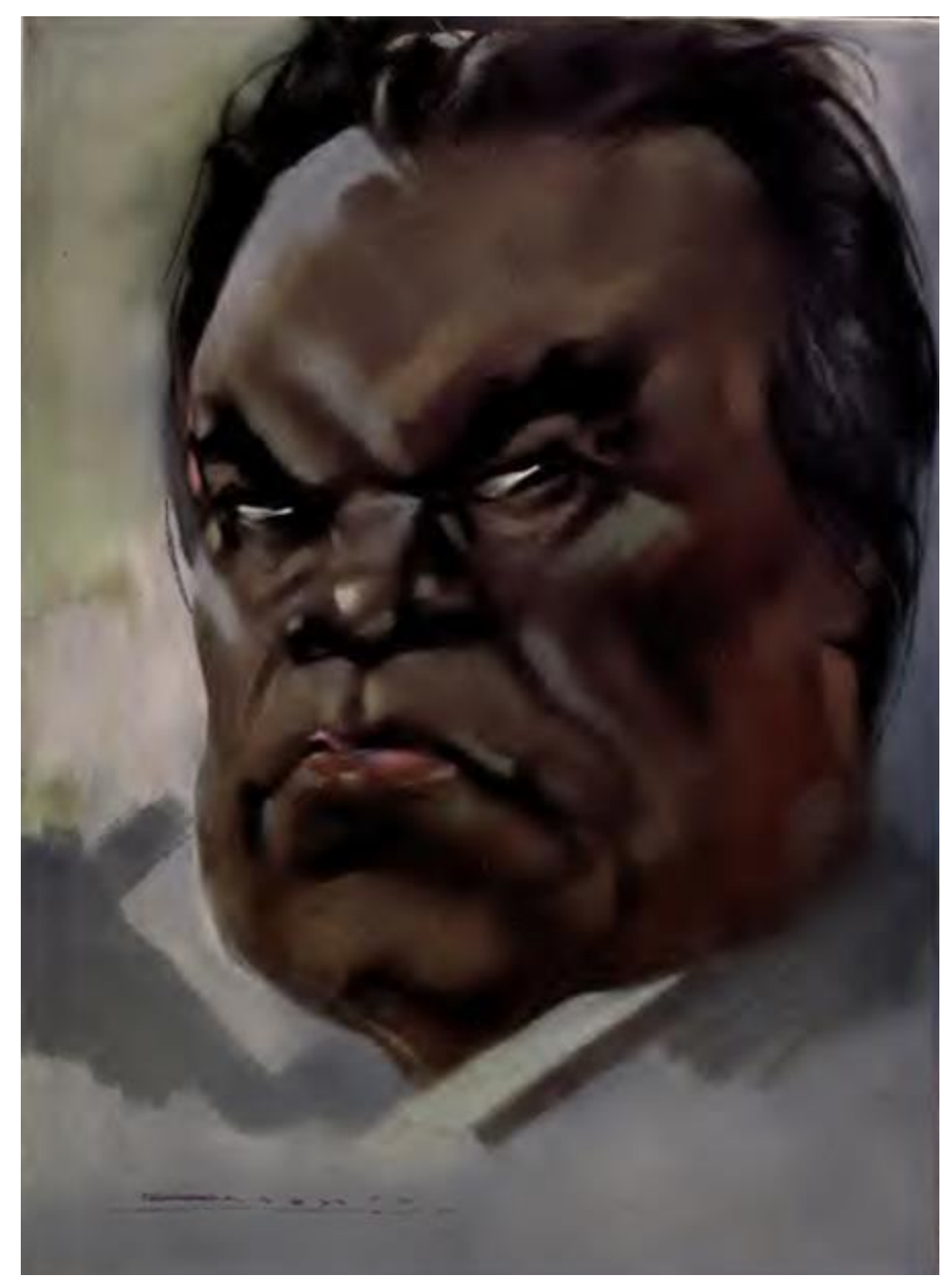

IMAGEM 3 - RUBÉN DARÍO

Juan Carlos Alonso.

"Plus Ultra”, Buenos Aires, Año I, Nº 2, 1916

O que lemos nessa cabeça? Laura Malosetti Costa nos relembra que, na revista Mundial, editada em Paris, Darío mantinha uma seção sempre acompanhada por um retrato - literalmente una "cabeça", desenhada por um artista (quase sempre o espanhol Vázquez Díaz). É possível vincular essas associações de retratos escritos e desenhados com o projeto (finalmente frustrado) de ilustrar Los Raros com desenhos de artistas argentinos, alguns dos quais apareceram na imprensa de Buenos Aires, assim como a presença de sua "cabeça", desenhada por Schiaffino, surge na capa daquele livro, com o qual 
Darío desdobrou seu ideário estético nos anos do Ateneu portenho. Embora fossem frequentes os retratos desenhados por ilustradores nos jornais, é plausível pensar que essas "cabeças", por meio das quais Darío colocava seu texto em sintonia com a obra de um artista, foram o lugar preciso da associação entre imagem e ideal, que Darío tinha em mente, a partir daquela série de críticas no jornal La Prensa de Buenos Aires. O retrato sempre foi o gênero artístico que mais lhe interessou, algo talvez chocante no momento em que a veracidade indiscutida da fotografia se põe ao serviço da frenologia positivista. No caso do retrato de Darío executado por Alonso, chamam-nos a atenção não apenas a força dos músculos do rosto, que conformam uma massa compacta e quadrada, mas também o olhar luciferino, definido apenas com duas pinceladas brancas. De fato, há na imagem de Alonso um sentimento de tensão e nostalgia desconsolada porque o poeta desaparecido, diz a epígrafe, era um guia inquestionável, que apenas poderia ser comparado a Beethoven ${ }^{8}$, apesar de que, para o próprio Darío, Beethoven reencarnara, na verdade, no musicólogo José Ojeda, seu confrade do grupo de La Syringa (cujo núcleo, além de Ojeda, era formado por José Ingenieros, Antonio Monteavaro, José Pardo e Luis Doello Jurado e, um pouco mais distantes, Eugenio Díaz Romero, Ricardo Jaimes Freyre, Leopoldo Lugones, Américo Llanos, José León Pagano, Charles de Soussens, Mauricio Nirenstein, assim como os irmãos Luis e Emilio Berisso). ${ }^{9}$ Mas não nos esqueçamos que o protagonista de El oro de Mallorca (1914), o romance inacabado de Rubén Darío, é também uma sorte de alter

\footnotetext{
8 "Su rostro era parecido al de Beethoven. Sus estrofas son también suaves y fuertes, como las cadencias del genial músico. Porque ostentaba en su faz y en su arte el sello de la grandeza. Fué un creyente descreído, un millonario excéntrico que pedía limosna de amor para los humildes, imitando a los monjes mendicantes. Creímos en él, y le reservamos el mejor sitio de nuestras páginas, sin sospechar que pronto le habríamos de rendir este último homenaje." Plus Ultra, n. 2, mar, 1916.

9 "Ojeda era nuestro Beethoven / y su piano daba su cántico", diz Darío nos "Versos de Año Nuevo" (1910). Anos antes, em 1904, José Ingenieros assim definia a confraria que, segundo Arlt (em Saverio el cruel), não passava de uma "peña de cachadas": "La Syrhinga, institución de estética y de crítica, preexiste, existe y subsiste. Es un exponente del espíritu dionisíaco y, como él, remonta su origen hasta la primera sonrisa del piteco ancestral. Todo syrhingo es dionisíaco; puede, ulteriormente, ser apolíneo. El carácter de syrhingo no se confiere u otorga; se reconoce y comprueba. El espíritu syrhingal reviste gradaciones; en la América Latina alcanza hasta el quinto grado; se ignora la existencia de grados superiores, pues nadie puede presumir ni comprobar cualidades que exceden de su comprensión." apud TARCUS, Horacio. Espigando la correspondencia de José Ingenieros. Modernismo y socialismo fin-de-siècle. Políticas de la memoria, n. 10-11-12, Buenos Aires, 2011-12, p. 103.
} 
ego, um pianista chamado Benjamín Itaspes. ${ }^{10}$ Seja como for, Darío disse que "la cabeza de Ricardo Rojas, la cabeza física, es la de un cacique."11 Em sintonia com essa ideia, Alonso busca além, no traço denso de seu retrato de Darío, não apenas a contundência do novo, mas também aquela que dá conta da fragmentação da própria modernidade, a qual sua revista encarna como poucas.

Para melhor avaliá-lo, comparemos essa figuração do poeta com o retrato feito por Victor Delhez em 1933 (imagem 4). Apesar do artista belga, amigo de Michel Seuphor e representante local de L'Esprit Nouveau, ter ensaiado, pioneiramente, em seu autorretrato, a técnica da raiografia, ao estilo Man Ray, e mesmo a despeito de que essa questão anacrônica aparecesse, frequentemente, em suas montagens, nos primeiros números de Sur, onde

${ }^{10}$ Ali lemos: "El arte, como su tendencia religiosa, era otro salvavida. Cuando hundía, o cuando hacía flotar su alma en él, sentía el efluvio de otro mundo superior. La música era semejante a un océano en cuya agua sutil y de esencia espiritual adquiría fuerzas de inmortalidad y como vibraciones de electricidades eternas. Todo el universo visible y mucho del invisible se manifestaba en sus rítmicas sonoridades, que eran como una perceptible lengua angélica cuyo sentido absoluto no podemos abarcar a causa del peso de nuestra máquina material. La vasta selva, como el aparato de la mecánica celeste, poseía una lengua armoniosa y melodiosa, que los seres demiúrgicos podían por lo menos percibir: Pitágoras y Wagner tenían razón. La Música en su inmenso concepto lo abraza todo, lo material y lo espiritual, y por eso los griegos comprendían también en ese vocablo a la excelsa Poesía, a la Creadora. Y que el arte era de trascendencia consoladora y suprema lo sabía por experiencia propia, pues jamás había recurrido a él sin salir aliviado de su baño de luces y de correspondencias mágicas. ¿Era asimismo un paraíso artificial? No, puesto que en el secreto de su poderío uno no podía disponer de él sino él de uno, él era el que poseía y se hacía manifiesto por medio del deus, sus excelencias resplandecían intensamente en nuestro mundo incógnito, anunciadoras siempre de un resultado bienhechor que nunca engañaba. Y quizá esta era la verdadera compensación para el elegido que venía al mundo con su emblemático signo y con su sagrado cilicio. Dios está en el Arte, más que en toda ciencia y conocimiento, y la santidad, o sea el holocausto del existir, no es sino el arte sumo elevado a la visión directa del Completo teológico, purificado por lo infinito del fuego de los fuegos. Es la locura del Señor. Stultitia dei." DARIO, Rubén. El oro de Mallorca. La Nación, Buenos Aires, 7 dez. 1913, p. 11. Darío chegou a usar o pseudônimo Levy ltaspes, onde chama a atenção a recorrência, como no seu pseudônimo mais famoso, Rubén, não apenas da figura do judeu (Levi é o terceiro filho de Jacob e Lía), mas também a condição errante (na figura de outro pseudônimo, Ashaverus, o que vive eternamente sem trégua nem descanso, como dizia Quiroga). Euclides da Cunha denominará Judas Ashaverus aqueles seres amazônicos, À margem da História, que mais tarde conheceríamos como homines sacri. O sobrenome Itaspes é um mero anagrama, não apenas de aseptisé, mas também de pesetas, o fantasma da mercantilização artística, o ouro de Mallorca. O salgueiro, choupo ou chorão se diz em inglês aspen. It aspes=isso chora, ou seja o yolleo de Girondo. Em um poema em resposta a críticas ("A Ricardo Contreras"), Darío admite: "mi callada voz dice tan sólo / baja canción, cual la que dice el ave /en el sauce que cubre el mausoleo."

${ }^{11}$ DARIO, Rubén. Ricardo Rojas; Cabezas. In: Semblanzas. Madrid: Afrodisio Aguado, 1950, v. II, p. 908. 
Delhez pratica aliás autênticas experiências de museu imaginário ou atlas Mnemosyne ${ }^{12}$, o retrato em xilografia de Darío para a revista Poesía (ilustrando por sinal um texto de Arturo Marasso, que antecipa sua leitura filológica de Rubén Darío y su creación poética), é convencional e nada capta nele do movimento tortuoso que o próprio Delhez tinha ensaiado, pouco antes, nas suas ilustrações para As flores do mal de Baudelaire. Pelo contrário, Alonso capta melhor que Delhez a dinâmica da arte como um confuso turbilhão da vida (sua origem) e, em seu retrato de Darío, evoca, por exemplo, a linguagem plástica de Rodin. Não esqueçamos que, poucos anos antes, em um dos ensaios de Philosophische Kultur (1911), o já citado Simmel tinha incluído um texto sobre este escultor e o que poderíamos chamar um impressionismo atemporal, que é possível expandir até Darío, cuja imaginação, contraditória e complementar, baseia-se, segundo Octavio Paz, no dinamismo.

\footnotetext{
${ }^{12}$ No primeiro número de Sur, verão de 1931, Borges reedita "Séneca en las orillas", um desses textos no qual duvida da existência da literatura e propõe no seu lugar a leitura. Interessa destacar desse texto, que já tinha passado por Síntesis de Martín Noel e por esse libro dedicado a um rubeniano como Evaristo Carriego, que o mais relevante é, do meu ponto de vista, a leitura de imagens em obediência a uma quarta dimensão. Exemplifico com uma frase aparentemente menor, que o próprio Borges encerra entre parêntese: "(Esa posesión temporal es el infinito capital criollo, el único. A la demora la podemos exaltar a inmovilidad: posesión del espacio.)" BORGES, Jorge Luis. Séneca en las orillas. Sur, n. 1, 1931, p. 175. As imagens de Delhez para as inscrições de carro, mas também da hélice ou do peixe, nas páginas de Sur, são esse infinito capital que indica possessão temporal e se conectam com suas apocalípticas visões de arquitetura e nostalgia. Mas, no caso de Borges, ao criticar a possessão do espaço, porque, em última instância, Sêneca, um marginal, um espanhol filosofando em latim, volta a se marginalizar nas inscrições de carro, em que a demora é usada para dar dinamismo à própria leitura, quer dizer, para introduzir a différance.
} 


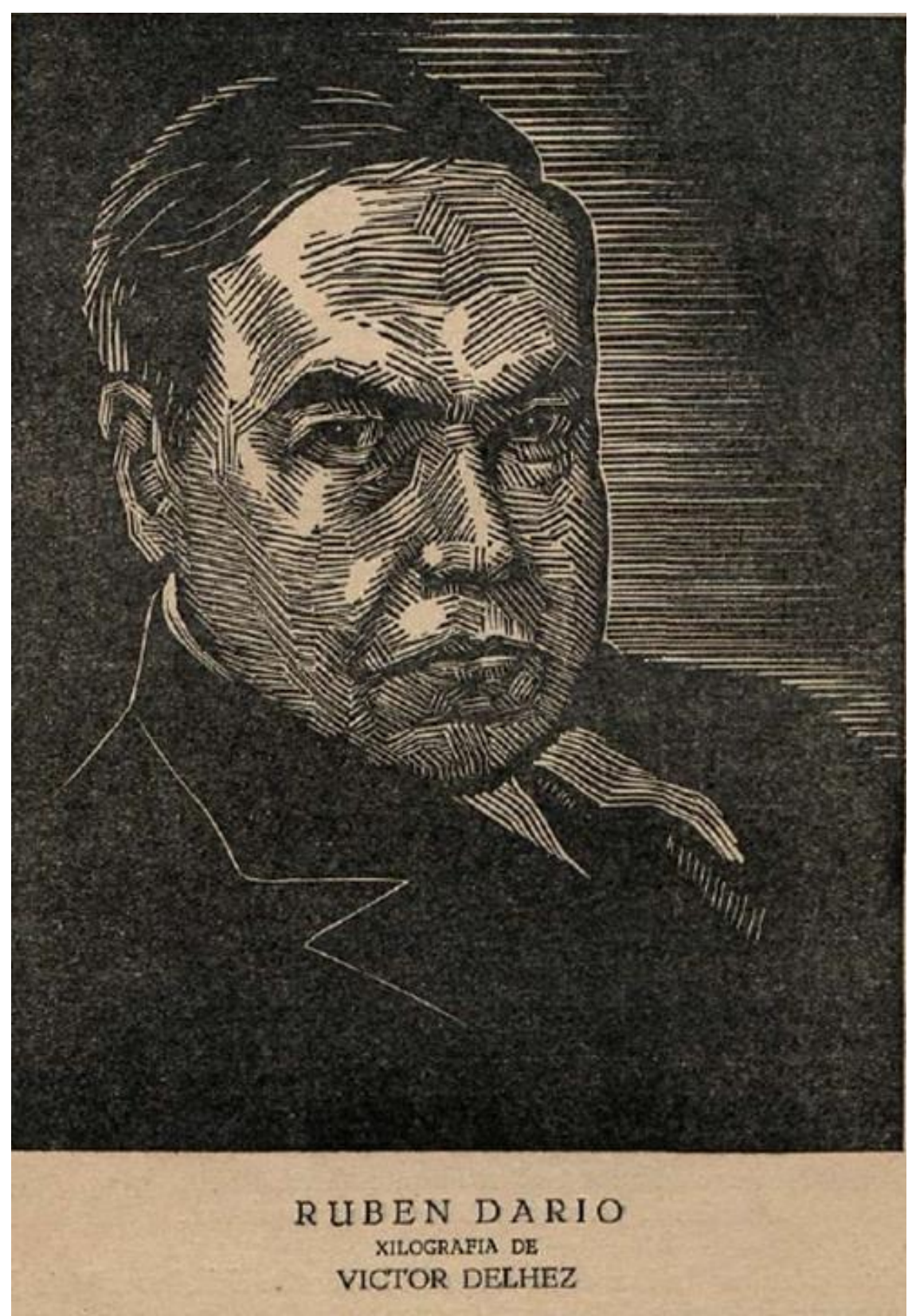

De fato, Simmel argumentava que, com Rodin, o acento abandona a forma e se desloca em direção ao movimento: o equilíbrio entre o movimento e a substância corporal é obtido agora em um plano dinâmico mais alto que o normal. A pressuposição prévia ou, se preferirmos, o tom fundamental da harmonia alcançada pelo artista clássico era o puro corpo, a estrutura plásticoabstrata, enquanto que, nos modernos, como Rodin ou Darío, trata-se do movimento, que abre novos campos e novos meios de expressão. Paradoxalmente, encontro, no arquivo, uma imagem abúlica e adinâmica que se nos 
apresenta como sintomática. Horacio Quiroga confessa a Lugones, ao ver, precisamente, uma foto de Rubén Darío em Caras y Caretas, a foto da qual partimos, obtida durante a inauguração do Ateneu Hispano-americano, que o rosto de Darío, caído, torcido, carrancudo, era o de um autêntico Cristo. ${ }^{13}$ É sintomático, portanto, que Alonso, ao estampar este Darío póstumo, dispense o tronco e se concentre no rosto, porque aquele apenas nos revelaria o homem no fluir de sua vida interior, enquanto este Ecce Homo o faz em sua substância permanente e duradoura. Mas isto, além do mais, se estende às figuras extraídas dos poemas, com que Alonso brinda aos seus leitores. Não é fortuito que ele prolongue, então, esse caráter próprio do rosto a todo o corpo e, às vezes, as caras são menos características e individuais, já que toda a mobilidade da sensibilidade, toda sua paixão, que em geral encontra seu lugar natural de expressão no rosto, revela-se nos gestos do corpo, em todas as vibrações que, partindo do centro do sujeito, se amortecem ou aceleram com a opressão ou ligeireza deste corpo.

Haveria aqui, nestes textos modernistas ilustrados por Alonso, ou em seus retratos de outras personalidades como Guido y Spano, Amado Nervo ou Roosevelt, uma vitória do tom naturalista. Mas não se trata de um naturalismo vulgar, que procura refletir apenas os conteúdos das coisas tais como são. $O$ naturalismo extremado aborrece do estilo, sem se dar conta de que um estilo que vive, com imediatez, o sentido de nossa vida é muito mais profundamente verdadeiro, fiel à realidade, que qualquer imitação: não apenas contém verdade, mas ele é a própria verdade. Falsamente mimético, ele incorpora, apesar de tudo, um pathos sem cabimento no naturalismo positivo e cinde-se assim entre o alto (a águia, a catedral) e o baixo (Nemrod, as ruinas pagãs). Não pinta a coisa, mas o efeito que esta produz, como explica Mallarmé na carta a Cazalis. Pinta a Coisa.

Ao contrário, o artista moderno seria libertário porque representa, com suprema perfeição, essa vida que se dissemina na paixão dinâmica e, fazendo com que a vivamos na esfera da arte, nos liberta dela, tal como a sentimos no plano dos fatos. Nas palavras preliminares a Prosas profanas, Rubén Darío tinha insistido na hipótese da disponibilidade temporal, argumentando que, caso haja poesia em nossa América, ela está nos vestígios pré-colombianos, no índio legendário e no inca sensual e fino, no grande Moctezuma da cadeira de

${ }^{13}$ TARCUS, Horacio (Ed.). Cartas de una hermandad. Buenos Aires: Emecé, 2009, p. 87. 
ouro. ${ }^{14}$ Por isso vale a pena observar que, logo no primeiro número de Plus Ultra, na sua página central, que funciona justamente como janela cinemascópica para a história, o próprio Juan Alonso ilustrava um poema muito significativo de Darío, "Tutecotzimi", concebido como escavação no palimpsesto da história latino-americana. A ideia já estava exposta em "Friso" e "Palimpsesto", duas "Recreaciones arqueológicas" de Prosas profanas, apesar de que o âmbito era ainda nestas o da Hélade. Agora, porém, o espaço "anduvo, anduvo, anduvo", tornou-se americano e isso significa escolher um episódio evolutivamente perimido, se levamos em conta a caricatura anexa, que mostra uma conferência ilustrada sobre esse método bárbaro de montagem de tempos dissímeis. É que o arquivo é ali interpretado pelos redatores como acumulação empírica de provas contundentes, mas higiênicas, para nos persuadir a respeito do caráter evolutivo da cultura e seu naturalismo irrecusável. Basta recordar a imagem de Florentino Ameghino (imagem 5), cercado por suas caixas de peças e vestígios pré-históricos. Mas Darío nos diz outra coisa. Diz que essas caixas, esses arquivos que são os poemas, não apenas contêm verdade, mas são a própria verdade e, nesse sentido, há verdade, porém, ela está deslocada e é necessário rearmá-la a posteriori, tal como ele próprio propôs com Netzahualcoyotl ou Cuauhtemoc, em sua ode a Roosevelt. Por tanto, se Darío, como Rodin, é o movimento, devemos também nos mover pelo arquivo para entender mais cabalmente como ler um signo tão

\footnotetext{
${ }^{14}$ Um interlocutor de Evaristo Carriego, Àlvaro Melián Lafinur, primo do pai de Borges, é um dos que enaltece esse aspecto de uma obra (que "evocó a la Atlántida precolombiana, exhumó las civilizaciones de la América primitiva y se inquietó por el destino de esa misma América." LAFINUR, Àlvaro Melián. Rubén Darío. Nosotros, a. 11, t. 25, 1917, p. 148), como a de Rubén Darío, com quem, além do mais, compartilhava orientalismo (Darío prefaciou a tradução de Rubaiyat, precedida por texto crítico de Lafinur e editada por Nosotros). Rubén, Melián Lafinur (a escritura de curral, Borges...) compreendem assim que surge por esses anos um novo modo de escritura, gerado pela exegese alegórica dos hieróglifos. Será a tese central do modelo das paisagens benjaminianas. Ao dia seguinte de sua morte, Melián Lafinur publica, em La Razón, um esboço no qual destaca que "Rubén Darío apareció en el momento en que reinaba en la literatura, en la filosofía y en el arte ese triste desconcierto ideológico y esa enfermiza instabilidad moral. Por eso se encerró al principio en un individualismo indiferente y un tanto egoísta. Puesto que no había en el mundo a la sazón fuertes ideales a que adherir, prefirió cultivar a solas las rosas de su huerto sellado. De ahí nacieron aquellas Prosas Profanas, en que sólo un propósito artístico - la pureza de la línea como en el mármol, la opulencia del colorido como en la tela, la armonía de los sonidos como en la música - preocupa al cantor, alejado de las turbulencias del mundo y de las disputas de los hombres. Ellas quedan como la expresión más alta de su genio artístico, no suficientemente humanizado todavía como para poner el oído a las voces de fuera, y penetrándose del clamor universal, interpretar, en estrofas de sentido imperecedero, cosas permanentes, eternas." Cf. Nosotros. Buenos Aires, a. 14, t .21, fev. 1916, p. 311.
} 
complexo e esquivo como "Tutecotzimi" (imagem 6). Antes de mais nada, recordar que a imagem do cacique antecipa, em dois meses, a eleição do presidente Yrigoyen, a quem hoje chamaríamos um populista; mas, além do mais, compreender que a imagem de Alonso nos auxilia a avaliar todo o processo (imagem 7). Ela suplementa e anuncia, logo no primeiro número de Plus Ultra, as mudanças por vir, não apenas nas gravuras de Alonso, mas também nas fotos de González Garaño, ilustrando as teorias de Martín Noel. ${ }^{15}$ É aquilo que Ricardo Rojas (retratado por Quirós em 1926) desenvolve em Eurindia (1924) e que também nos mostram os Dibujos decorativos americanos (1923) de Leguizamón Pondal y Cantilo; La Venus calchaquí (1924) de González Arrili, os Tejidos incaicos y criollos (1927) de Fausto Burgos e María Elena Catullo; os Siete ensayos de interpretación de la realidad peruana (1928) de Mariátegui, cuja capa é de uma discípula de Sabogal, Julia Codesido, e até mesmo a imagem do autor, de José Malanca. É o que mostra a Pacha Mama (1931) de Amadeo Sirolli, até chegarmos ao Redescubrimiento de América en el Arte (1941) de Ángel Guido, de tão decisiva marca em La expresión americana (1957) de Lezama Lima. É a linha do barroco de contra-conquista.

\footnotetext{
${ }^{15}$ Seu sobrinho analisaria as sobrevivências hispânicas do poeta. Cf. NOEL, Martín Alberto. Las raíces hispánicas en Rubén Darío. Buenos Aires: Universidad de Buenos Aires, Facultad de Filosofía y Letras, Secretaría de Extensión Universitaria, 1972.
} 


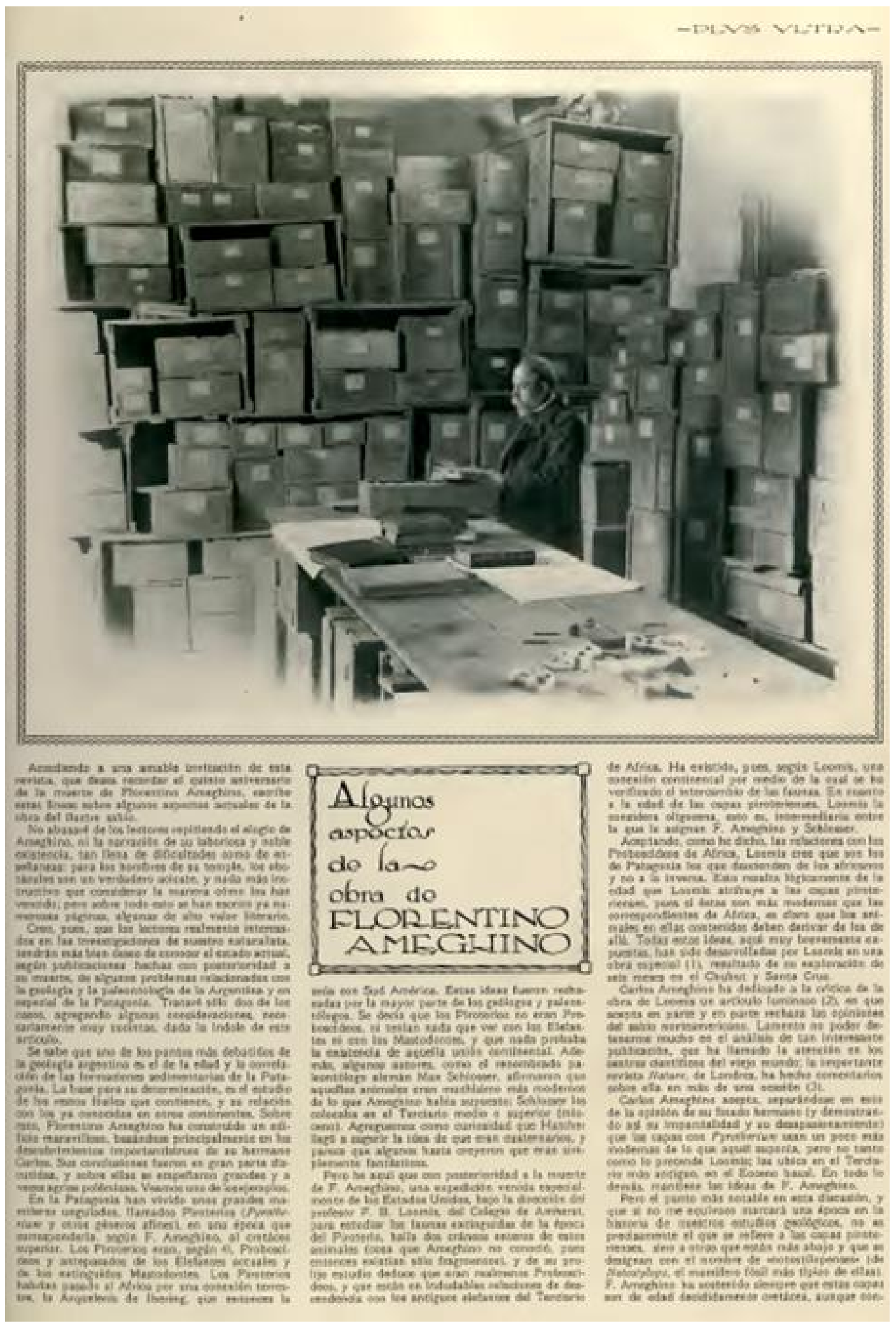

IMAGEM 5 - ALGUNOS ASPECTOS DE LA OBRA DE FLORENTINO AMEGHINO Martín Doello-Jurado.

"Plus Ultra”, Buenos Aires, Año I, N 5, 1916

| boletim de pesquisa nelic, florianópolis, v. 16, n. 25, p. 3-31, 2016 | 


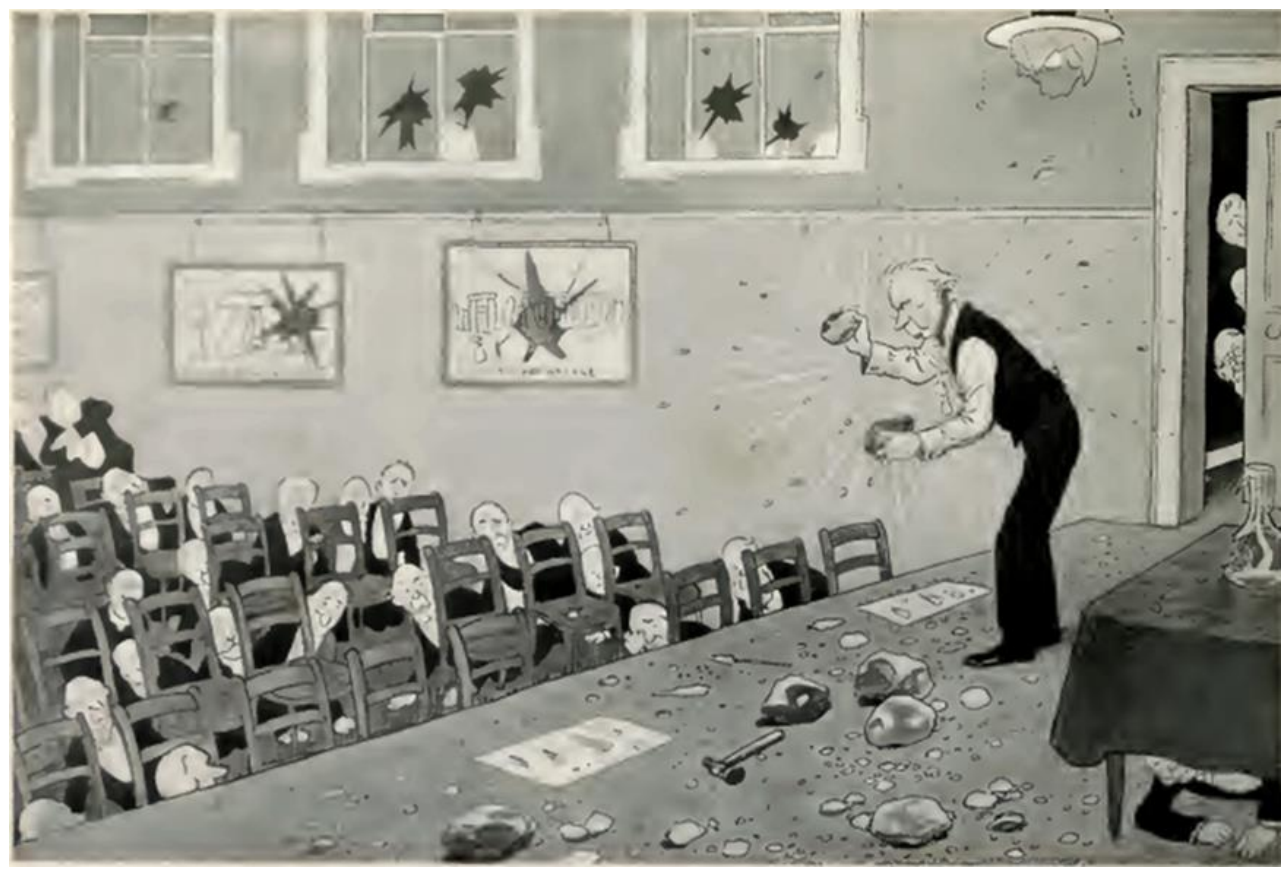

IMAGEM 6 - CONFERENCIA CIENTÍFICA

Un miembro de la Sociedad de Arqueologia, demonstrando la manera que empleaban los hombres primitivos para fabricar puntas de piedra para flechas. (Dibujo de Morrow).

"Plus Ultra”, Buenos Aires, Año I, Nº 1, 1916

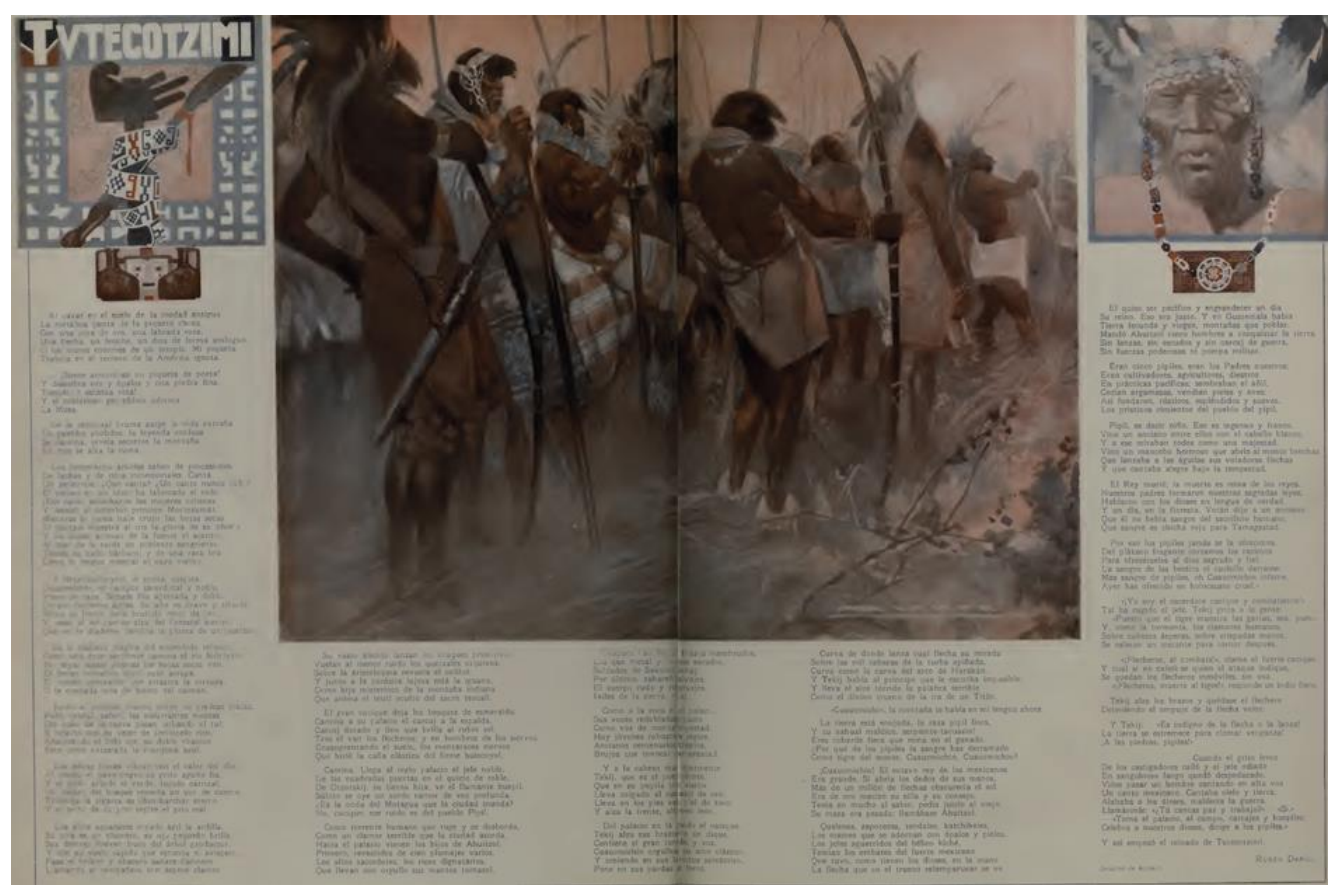

IMAGEM 7 - TUTZECOTZIMI

Rubén Darío, ilustrado por Juan Alonso.

"Plus Ultra”, Buenos Aires, № 1, mar. 1916

| boletim de pesquisa nelic, florianópolis, v. 16, n. 25, p. 3-31, 2016 | 
Mas desloquemos o olhar para tanto. No quarto número de Plus Ultra, é também Alonso quem ilustra "La marimba", do poeta guatemalense Francisco P. Figueroa (imagem 8). O naturalismo filtra-se aqui como um som rouco e profundo. O poema de Figueroa traça uma ponte sutil com o de Darío, acompassado pelo toque da marimba. Instrumento de ascendência africana, mais especificamente banto, segundo Artur Ramos (ao qual se associa, apesar de haver registros de seu uso em Cuba e no Brasil, com setores subalternos guatemalenses, indígenas e ladinos pobres), a marimba, por sua vez, nos conduz retrospectivamente a esses mesmos rostos que Alonso retrata, sem qualquer motivação etnográfica, no poema de Darío, apesar de que aqui se tornem mais enigmáticos, se cabe, porque cadenciados pela marimba, em "una extraña sinfonía / saturada de amargura y de cruel melancolía / con sus teclas de madera..."

16 "Yo no sé que oscuro arcano / de tristeza hay en lo hondo / de esa música salvaje, que palpita allá en el fondo / de sus notas como queja /dolorosa./ Como un gemido humano, /como algo que solloza, /como un dolor latente, / como algo inexplicable, infinitamente triste. / Es el alma de una raza; /de una raza que no existe, /de una raza ya extinguida, libre, indómita y valiente. (...)¿Qué le importa al indio eso /que llamáis pomposamente libertades y progreso,/si es del amo su cabaña, si del amo son sus hijas y su esposa?/¿Qué le importa? Si de aquella raza libre, brava y fuerte, /que sufrió sin inmutarse los tormentos y la muerte, /habéis hecho solamente las acémilas de carga, /que se arrastran tristes, mudas bajo el peso /de su amarga dura suerte. ¡ $O$ Oh! Dejadla que solloce, que se queje a su manera;/solamente le ha quedado su marimba de madera, /que le habla de sus tiempos victoriosos." FIGUEROA, Francisco P. La marimba. Plus Ultra, Buenos Aires, n. 4, abr. 1916. Sobre a questão, ver ARMAS LARA, Marcial. Origen de la marimba, su desenvolvimiento y otros instrumentos músicos. Guatemala: Tipografía Nacional, 1970; TARACENA ARRIOLA, Jorge Arturo. La marimba: ¿un instrumento nacional? In: Tradiciones de Guatemala. Guatemala, Centro de Estudios Folklóricos, n. 13, 1980; CARDENAL, Ernesto. La democratización de la cultura. Managua: Ministerio de Cultura, 1982. Mário de Andrade nos oferece uma documentada descrição da marimba: "Instrumento de percussão de origem africana, traves ou arcos de madeira sobre as quais são apoiadas teclas de madeira e cabaças como caixas de ressonância, uma para cada tecla; a marimba é percutida com vaquetas. Artur Ramos Pereira afirma que o instrumento 'provém dos povos bantos' e que 'também é chamada marímbula, em Cuba (...).' (As culturas negras no Novo Mundo, 1937, p. 151). Para Stephen Chauvet, marimba é o nome do xilofone em Angola, para os povos Balubas, Azandes e Babundas (Musique Nègre, 1929, p. 84), enquanto George Montandon fornece o sinônimo balafon (Traité de ethnologie culturelle, 1934, p. 110) Schaeffner e Coeuroy recensearam ainda os sinônimos handja, timbila e anzang, no Congo, Zambeze e Madagáscar ( Le jazz, 1926, p. 45). (...) Usada também entre os africanos do Brasil. Melo Morais Filho enumera a marimba entre os instrumentos acompanhantes dos cucumbis cariocas. (Festas $e$ tradições populares do Brasil, s.d., p. 158)." ANDRADE, Mário de. Dicionário musical brasileiro. Oneyda Alvarenga, Flávia Camargo Toni (Coords.). Belo Horizonte; Itatiaia; Brasília: Ministério da Cultura; São Paulo: IEB/EDUSP, 1989, p. 308-309. 


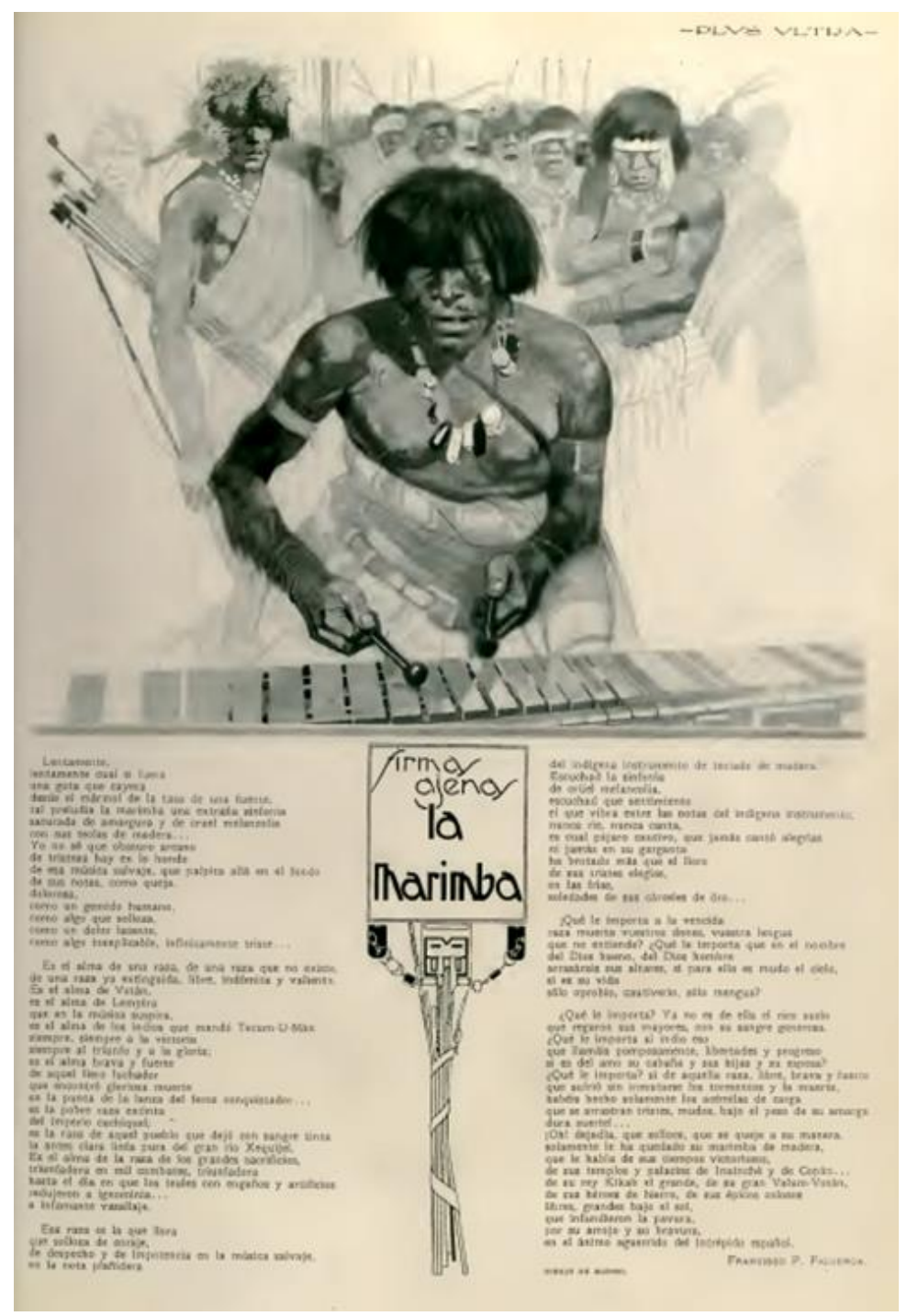

IMAGEM 8 - LA MARIMBA

Francisco P. Figueroa, ilustrado por Juan Alonso.

"Plus Ultra”, Buenos Aires, Año I, Nº 4, mar. 1916

No entanto, nem o poeta, e menos ainda o ilustrador, mostram-nos um aspecto encoberto, secreto ou transgressivo, no toque da marimba, cujo som é quase tão inócuo como o de um sino de madeira (Campana de palo será o título de uma revista ligada à boemia anarquista em 1925). De fato, em uma obra sobre os ciganos portugueses, o filólogo Adolpho Coelho nos informa que o verbo marimbar já tinha uso corrente no século XIX, como equivalente de enganar, rir de alguém, desacatar, coisa que não devia ser desconhecida por um espanhol, mais ainda, um galego como Alonso. Mas nada, nessas cabeças de primatas que ele pinta, permite-nos pensar em uma transgressão de normas cultas que, à maneira de La Syringa, criasse uma nova sociabilidade: 


\begin{abstract}
Al canto mio el tiempo parecerá mas breve; como Pan en el campo haré danzar los chivos; como Orfeo tendré los leones cautivos, y moveré el imperio de Amor que todo mueve.

Y todo será, Syrinx, por la virtud secreta que en la fibra sutil de la caña coloca con la pasión del dios el sueño del poeta;

porque si de la flauta la boca mia toca el sonoro carrizo, su misterio interpreta y la harmonia nace del beso de tu boca. ${ }^{17}$
\end{abstract}

Pelo contrário, na cena dos índios tocando a marimba, apenas há um canto elegíaco de vencidos; e a eventual confusão entre marimba e berimbau, identidade sobre a qual também não há consenso, está longe de poder pôr o corpo na dança e mostrar uma ação que seja de desafio e confronto. Poderíamos inclusive ouvir uma polifônica percussão beligerante nesse significante aglutinador: marimba, djumba, ekende, iansé, ibeka, kansambi, kibanda, quimbanda, kisachi, kizanza, likembi, lulumba, lusukia, marímbula, maringa, mbichi; pokido, sanza, zimba. Mas não há isso. A revista Plus Ultra quer positivamente se discriminar do fetichismo (ver a matéria no n. 4), quer falar do factício, do fabricado, do falso, do fingido, daí que esse conceito cubra, no seu discurso, o sentido de sortilégio, amuleto, necromancia, ou seja, as duas vertentes, uma ascendente, outra descendente, do próprio fenômeno do feitiço social do moderno.

Veja-se, que, ao contrario, ainda nesse mesmo número de Plus Ultra, em "Ezuauacatl", o texto de Leonor Allende ilustrado pelo seu marido, o cientista Guido Buffo, predomina uma reconstrução lírico-destinal do comunitário, que se materializaria muito mais tarde, anos 30, quase em paralelo com o "Exercício plástico" de Siqueiros, na capela em forma de botão de cardo santo, tal como no imaginário de Karl Blossfeldt, que o próprio Buffo levantou em Unquillo, na província de Córdoba. Para sua acústica, longe das fúnebres madeiras de uma marimba ou do teponaxtli, pensou-se em uma experiência

${ }^{17}$ DARIO, Rubén. Syrinx. In: Poesias, op.cit., p. 239. 
dariana, o som obtido ao inverter um caramujo marinho ${ }^{18}$, o que, para Buffo, representava o interior da terra, mas, para o cúmulo de sincretismo, o homem de ciência não duvidou em gravar também, sobre a parede de entrada ao seu templo, os acordes iniciais da Quinta Sinfonia de Beethoven e a oração de Jesus no horto, tomada da Paixão segundo São Mateus, pentagramas pelos quais, finalmente, se tinha acesso a uma série de murais, "Elogio a Dios", "Elogio al sentimento" e "Elogio al intelecto", pintados no interior da íntima capela. ${ }^{19}$ Como se constata, o dinamismo, de estirpe dariana, aquietado já nos anos 30, leva-nos agora, por outras vias, ao ensimesmamento decorativo,

${ }^{18}$ Em uma peça tardia, "Poema del otoño", diz Darío: "Nuestro cráneo guarda el vibrar / de tierra y sol, / como el ruido de la mar / el caracol. / La sal del mar en nuestras venas / va a borbotones; / tenemos sangre de sirenas / y de tritones./ A nosotros encinas, lauros, / frondas espesas; / tenemos carne de centauros / y satiresas. / En nosotros la Vida vierte / fuerza y calor./ ¡Vamos al reino de la Muerte/ por el camino del Amor!” Ibidem, p. 367. O primeiro em assinalar essa relação foi Juan Ramón Jiménez (Españoles de tres mundos. Viejo Mundo, Nuevo Mundo, Otro Mundo. Buenos Aires, Losada, 1942) e dali o toma Octavio Paz para seu "El caracol y la sirena" (Cuadrivio. México: Joaquín Mortiz, 1965).

${ }^{19}$ Em "América desaparecida" (1928), Bataille reivindicaria a excentricidade sanguinária de certas cerimônias com cadáveres e rios de sangue, que evocam não tanto uma aventura histórica concreta, mas os deslumbrantes excessos descritos pelo marquês de Sade. Leonor Allende também recorda uma luta pré-hispânica, narrada por Diego Durán na Historia de las Indias de Nueva España y islas de Tierra Firme (México, Imp. de J. M. Andrade y F. Escalante, 1867), em que tenochcas e chalcas lutam pelo mesmo espaço. Um príncipe de Tenoch é aprisionado e conduzido à capital inimiga, Amecamecau, onde se celebraria a grande festa do deus Camasetli. O príncipe Ezuauacatl era um destro mancebo saído do Calmecac, o colégio da nobreza local. "Ninguno en el ejército tenochca le aventaja en valor y es por su linaje de los primeros. Moctezuma Illhuicamina, nuestro emperador, tiénelo por el más cercano y querido de sus parientes." Será sacrificado. "Doraba apenas el alba la cresta de los montes cuando los sacerdotes del templo de Camaxtli hicieron oir la voz tremebunda del teponaxtli (un instrumento de sonido sordo y amenazador, la marimba de esa cultura), anunciando al pueblo chalca que la hora de la fiesta y de los sacrificios era llegada." O príncipe tenochca Ezuauacatl preferiu morrer se lançando do alto do teocali, antes do que reinar em um povo inimigo de sua pátria. Como nos casos dos sacrifícios astecas ou de Numancia, estudados por Bataille, durante a guerra, Ezuauacatl "se arrojó desde lo alto del madero, cayendo pesadamente sobre el duro pavimento. Cuando los sacerdotes se acercaron a él, estaba muerto ya. Y los chalcas vieron morir sin un grito de dolor a los cien tenochcas sacrificados uno por uno en honor del dios Camaxtli." BUFFO, Leonor Allende. Ezuauacatl. Episodio histórico mejicano. Plus Ultra, n. 4. Buenos Aires, abr. 1916. Guido Buffo ilustra a tese bataillana de que o homem não morre, mas se suicida e assim deveríamos ver seu desenho para a cena do sacrifício no teocali. Mais tarde, Buffo teorizaria as virtudes estéticas, sempre tomadas em tom de nobreza, como caminho de salvação. Cf. BUFFO, Guido. La educación estética en la enseñanza primaria y secundaria. El dibujo como expresión del sentimiento del raciocinio de la imaginación. Buenos Aires: Estrada, 1938. Não é descabido pensar, como linha de fuga do teocali de Unquillo, na ficção de Barón Biza ou no ensaísmo de Oscar del Barco. 
quando não à apática alogia. Daí derivam os primeiros questionamentos sobre a autêntica relevância de Darío como poeta. ${ }^{20}$

Mas gostaria de retornar ao elemento dinâmico, adormecido em "La marimba", ainda que não totalmente obliterado no poema prévio, em "Tutecotzimi". A imagem de Alonso é inspirada, evidentemente, por "La vuelta del malón", o óleo de Ángel Della Valle, analisado recentemente por Daniel Santoro. Respira o mesmo ar que as domesticadas imagens de Walter de Navazio, Ramón Silva, Martín Malharro ou Enrique Policastro. Mas não há nada nela do bucolismo de Eduardo Sívori, nem da metrópole moderna de Pio Collivadino, nem da miséria de Alfredo Lazzari ou de Eugenio Daneri. O espaço ocupado se conecta também, evidentemente, com uma linha de experiência plástica muito apreciada, não apenas por Rubén Darío, mas também pela cultura de massas, que é a pintura de batalhas. ${ }^{21}$ Artistas admirados pelo poeta como Édouard Detaille ou Alphonse de Neuville são eloquentes a esse respeito. Nessa linha de análise, poderíamos adicionar o espanhol Ulpiano Checa. Não apenas nas suas imagens de hunos e bárbaros espreitando os templos greco-romanos da república, mas também nas suas imagens equestres, como a do General Mitre, ou no imaginário orientalista que, na linha aberta na América por Monvoisin, tanto entusiasmo soube despertar em Sarmiento, mas que, nesses momentos de recolhimento íntimo, ainda era dominante em Joaquín Sorolla, artista emblemático do moderno para um crítico muito admirado também por Darío, Vittorio Pica. Ou inclusive em Anglada Camarasa, respeitado por Güiraldes mas desacatado por Duchamp. Dali provém, sem dúvida, o festivo imaginário militarista de Alonso, como vemos no desfile de granadeiros do terceiro número de Plus Ultra, que nos persuade de que há duas formas de exibição do poder, na sociedade modernizada: a posição da

${ }^{20}$ Um dos primeiros textos é assinado por uma mulher, Delfina Molina y Vedia, irmã de Julio Molina y Vedia, com quem Macedonio funda uma colônia anarquista no Paraguai (BASTIANINI, Delfina Molina; Vedia de. ¿Rubén Darío es un gran poeta? Nosotros, a. 11, t. XXV, n. 94, Buenos Aires, fev. 1917, p. 358-366). Quando, em El idioma de los argentinos (1928), Borges reivindique os precursores, cujo tom de escritura foi o da voz e sua boca não contradisse a mão, ao postular um crioulismo que não fosse de arrogância marginal, nem de mau humor, mas um dialeto usual daquela época, que não recaísse em espanholadas nem em chucrices, o escritor propunha, na verdade, algo fora de uso, o "decir bien en argentino". Em 1936, Delfina, que contrariamente a Amado Alonso e o Instituto de Filologia, defendia a tese do hispano-americano como nome da língua local, fundaria a Sociedade Argentina de Estudos Linguísticos (SADEL), cujo primeiro vice-presidente foi, precisamente, Borges.

${ }^{21}$ DARÍO, Rubén. Pintores de batallas. In: Obras Completas. Madrid, Afrodisio Aguado, 1950, v. 1, Crítica y ensayo, p. 725-729. Ver, contemporaneamente, PÉREZ REVERTE, Arturo. El pintor de batallas. Madrid: Alfaguara, 2006. 
categoria, mais arcaica e fundada no dispêndio fastuoso, e a da guerra, mais autônoma, porém também, a mais direta na destruição de todos esses bens acumulados no Centenário.

A imagem de Alonso (o arcaico Tutecotzimi) é publicada, portanto, em plena Guerra Mundial, em 1916, momento no qual o jogo bélico esgota os recursos do trabalho, porque, em sua essência, a guerra é um jogo terrível, ao qual o mundo hipócrita do trabalho, que buscava eliminá-lo (pense-se na geração dos ácratas que rodeavam Darío, começando por Ghiraldo ${ }^{22}$ ), negará tenazmente seu caráter de jogo. Sabemos disso e, com Benjamin aprendemos aliás que, contra a estetização da violência, só haveria o caminho da politização da arte. Mas como a própria humanidade é definitivamente um jogo, o elemento pós-humano, isto é, o homem da soberania renunciada, que emerge a rigor só após a Segunda Guerra Mundial, optaria por se situar na ótica da politização do discurso e, como tal, do próprio trabalho e, portanto, ele parece condenado a esse jogo inexorável, que já não tem nada de jogo, mas que agora traduz uma forma de esgotamento coercitivo na direção de mais e mais guerra, apesar de imaterial e disseminada, o que en passant sublinha que a revolução (estética) conduz, de fato, à guerra (histórica).

Nesse mesmo ano, 1916, sintomaticamente, Benjamin alerta seu amigo Martín Buber que a literatura poderia de fato influenciar a ética, mas não no sentido de um dever ser inequívoco, e sim no refluxo da ação sobre a linguagem, captando assim a parte maldita, o não mediatizável de seu percurso. $^{23}$ Por isso mesmo, diríamos, é nos momentos cerimoniais (e recordemos o peso que esse conceito tem para Mallarmé) que a sociedade põe a si própria em cena, através de gestos que revelam sua estrutura e seus códigos. É então quando a sociedade se separa do que é selvagem, ainda presente nos fetiches e nas marimbas, e adquire não apenas uma primeira forma de naturalismo, mas também de abstracionismo, colocando o heroico e o divino para além do humano. No entanto, é também, paradoxalmente, por meio do fetiche que o homem adquire uma forma de significar o humano, na medida em que já não há nada de natural entre o significado e a matéria que opera como

\footnotetext{
${ }^{22}$ A história do sacrifício infantil de um índio conclui com a observação de que "un poeta amigo (Rubén Darío?), que conoce esta historia, asegura, bajo la fe de su fantasía, que milache, en la lengua del niño indígena, quiere decir: jvenganza!" GHIRALDO, Alberto. La raza vencida: Milache. Plus Ultra, n. 1, Buenos Aires, fev. 1916.

${ }^{23}$ BENJAMIN, Walter. Carta a Martin Buber (jun. 1916). In: Correspondance I: 1910-1928. Trad. G. Petitdemange. Paris: Aubier-Montaigne, 1979, p. 117.
} 
significante. Pensemos nas ilustrações de Alonso para "El dinosauro" de Horacio Quiroga, narrativa que logo se integraria a "El sueño", de seu volume El salvaje (1920), imagens em clara sintonia com “El Salomón negro" de Darío. Essa imagem, em função de uma rede de correspondencias, não apenas espaciais, mas fundamentalmente de época, provoca-nos "regresión total a una vida real y precisa, como un árbol que siempre está donde debe, porque tiene razón de ser. Desde miles de años la especie humana va al desastre." ${ }^{24} \mathrm{~A}$ imagem, sendo disputa entre tempos diversos, é puro anacronismo. Ou então pensemos no retrato de Mallarmé traçado por Darío. ${ }^{25}$ Ou inclusive no que diz o próprio poeta, em "Tutecotzimí", que se descobre ali "una flecha, un fetiche, un dios de forma ambígua". Foi justamente essa falta de relação entre signo, sentido e significado que levou Marx a pensar o fetiche, quer dizer, a mercadoria enquanto tal, como a mediação entre trabalho e valor. Do mesmo modo, Freud também detectou, no fetiche, a forma transicional da imagem ao símbolo. Nesse sentido, a página duplamente selvagem de Alonso-Darío se elabora, compensa e expande, por exemplo, na dupla página fetichista do quarto número de Plus Ultra, atendendo à mesma premissa assinalada por Simmel, de que as figuras nos subtraem à febre e às oscilações problemáticas do nosso existir porque representam sua negação mais absoluta e sua mais nítida incontaminação.

Mais um caso. Pensemos na reportagem de Rafael Simboli, "Como se visita al Papa" (que lemos no n. 54 de Plus Ultra) ${ }^{26}$, e proponho que a associe-

24 "La formidable vida creada por el Querer del hombre y el Consentimiento de las edades muertas, no me era accesible sino de noche. (...) Vivía maquinalmente, adherido al horizonte contemporáneo como un sonámbulo, y sólo despertaba al primer olor salvaje que la frescura del crepúsculo me enviaba rastreando desde la selva. (...) Dentro de aquella forma negra y cargada de espaldas que trotaba a la sombra del dinosaurio, iba mi alma actual, pero dormida, sofocada dentro del espeso cráneo primitivo. Vivíamos unidos por el mismo destierro ultramilenario. Su horizonte era mi horizonte; su ruta era la mía." QUIROGA, Horacio. El dinosauro. Plus Ultra, a. 4, n. 35, Buenos Aires, mar. 1919.

${ }^{25}$ Esse ensaio inaugura uma linha que vai de "Borges y yo", em El Hacedor (1960), até Mario Bellatin, com Las dos Fridas (2008) ou Biografia ilustrada de Mishima (2009). Cf. DARIO, Rubén. Mallarmé. Notas para un ensayo futuro. El Sol del Domingo, Buenos Aires, n. 3, 18 set. 1898, p. 1; GARCIA MORALES, Alfonso. Un artículo desconocido de Rubén Darío: Mallarmé. Notas para un ensayo futuro. Anales de Literatura hispanoamericana, Madrid, Universidad Complutense, n. 35, 2006, p. 31-54.

${ }^{26}$ Colaborador em outras publicações como Repertorio Americano de Costa Rica ou Zig-zag de México, Rafael Simboli era frequente nas páginas de Caras y Caretas. Cf. Gabriel D’Annunzio y la guerra. In: Caras y Caretas, a. XIX, n. 933, 19 ago. 1916; Idem, Héroes civiles. Marconi y D'Annunzio. In: Caras y Caretas, a. XX, n. 990, 22 set. 1917; Idem, Caras y Caretas en Italia. El Papa y la guerra. In: Caras y Caretas, a. XVIII, n. 861, 3 abr. 1915; Idem, Caras y Caretas en Italia... Imprudencia pagada con la vida. El padre Cerbara y su gloriosa muerte. In: Caras y 
mos ao que, em maio de 1929, escreve Aby Warburg em seu jornal romano, o mesmo dia aliás da assinatura do tratado de Latrão, quando um imponente ritual ratificou o cerimonial: "ascensão imaginária e prática do sacrifício". 27

Mas se voltamos à figura do artista-empresário, cabe observar que, tanto a trajetória quanto a recepção artística de Juan Alonso são um exemplo eloquente e paralelo à própria fortuna de Darío. Logo após a sua estreia, em Caras y Caretas, o jornalista Eustaquio Pellicer, pionero cinematográfico no Prata, convida-o a colaborar na revista P.B.T., com uma caricatura de uma vedette, a Bela Otero; no ano seguinte, Alonso publica um retrato do poeta Guido y Spano na revista infantil Pulgarcito e, a partir de 1908, ele é colaborador também de Papel y Tinta e Vida Moderna, passando, desde seu lançamento, à Plus Ultra, que chegaria a dirigir. Imediatamente a revista conquista leitores por todo o continente. ${ }^{28}$ Não é o caso, porém, de seu diretor, cuja ambição de se tornar artista é severamente criticada. As revistas Martín Fierro e Campana de palo atacam-no duramente, quando expõe na galeria Witcomb, em $1924^{29}$, mas, sem desfalecer, Alonso reitera, na mesma galeria, em mais

Caretas, a. XIX, n. 947, 25 nov. 1916; Idem, Caras y Caretas en Italia. Las heroínas del trabajo. In: Caras y Caretas, a. XIX, n. 950, 16 dez. 1915; Idem, Caras y Caretas en Italia. Monumentos en Toilette de guerra. In: Caras y Caretas, a. XXI, n. 1005, 5 jan. 1918; Idem, Caras y Caretas en Italia. Vida cara. In: Caras y Caretas, a. XXI, n. 1024, 18 maio 1918.

${ }^{27}$ WARBURG, Aby. Miroirs de faille. À Rome avec Giordano Bruno et Édouard Manet, 1928-9. Ed. M. Ghelardi. Trad. S. Zilberfarb. Paris, Les presses du réel, 2011, p. 159.

${ }^{28}$ Já em 1921, Monteiro Lobato envia exemplares de Plus Ultra a seu amigo Godofredo Rangel. Escreve sobre Cesáreo Bernaldo de Quirós, por quem seria retratado, na sua Revista do Brasil e não pouparia elogios, um pouco mais tarde, ao próprio Alonso: "Todos los curiosos de las cosas conocen Plus Ultra, la incomparable revista bonaerense que desafía confrontaciones, y entre sus congéneres universales vive inimitable e inimitada. El equilibrio de su elegancia y el buen gusto inexcedible que preside su factura, la armonía de las partes, la calidad de los dibujos, títulos, adornos o viñetas con que se atavía, denuncian que hay en su dirección el espíritu de selección de un artista integral. Ese mago - todos lo sabemos - es Juan Alonso, nombre que afirma las más finas, las más atildadadas y vivas ilustraciones que aparecen en América del Sur..." apud VIÑUALES, Rodrigo Gutiérrez. Arte y emigración. Juan Carlos Alonso (1886-1945), un artista gallego en la Argentina. XIII Congreso Nacional del CEHA (Comité Español de Historia del Arte), Granada, 31 de octubre al 3 de noviembre de 2000, v. II, p. 763.

29 "Los personajes de Alonso son maniquíes de gran tienda", desafia, ao estilo Oliverio Girondo, o pintor Horacio Martínez Ferrer, para se deter, por exemplo, em "el hombre de la capa, que es un triste remedo de Velázquez. La cabeza de este personaje se destaca, como la dama, porque tiene luz interior como el foco de la esquina. El ambiente que los rodea es tétrico, opaco, obscuro, y ellos jtan refulgentes como una lamparilla de quinientas bujías! No obstante ser tan mala esta cabeza de hombre, sería aislada, de lo mejor realizado de la exposición. [...] En resumen, creemos que Alonso no puede ser pintor sino un común ilustrador de revistas. En todos los cuadros de la última muestra, a excepción de uno, se nota una carencia absoluta de sensibilidad, de vibración anímica. Y no puede ser artista el que, puramente objetivo, no descubre el alma de las cosas ni de los seres que pinta. (Para noso- 
duas ocasiões (1933 e 1937), sua conhecida estereoscopia histórica: a época de Rosas; a época atual. Sua linha de fuga seriam, ao término da guerra, as cenas e personagens do Martín Fierro de Hernández, como ilustração para os almanaques dos cigarros Avanti (1945). É o povo entrando, finalmente, em cena. Mas observe-se que, nessa evolução, reconhecem-se não apenas os avatares do rubenismo, tão reivindicado pelos novo-mundistas de inícios do século, como injuriado pelos vanguardistas de 1920, mas também as diferentes inflexões do moderno naturalismo que se impõe, sem maiores entraves, ao longo dos anos $30 .^{30}$

Toda a lógica da ficção, disse-nos Mallarmé, consiste nesse trabalho em duas frentes, aqui avançando, ali rememorando, um pouco no futuro, outro tanto no passado, sempre sob uma falsa aparência (factícia, fetichista) de presente. Nessa esquizofrenia trabalha o mímico, cujo jogo se limita a uma alusão perpétua, sem nunca chegar, no entanto, a quebrar o espelho, porque nele instala um meio, puro, de ficção. ${ }^{31}$ É no espelho, com distância e com atraso, que vemos aparecer esses espectros, embora sempre diferidos e fantasmagóricos, mutuamente inassimiláveis, tal como o mesmo e seu outro. Bruno Latour falará de deuses faitiches e William Marx chamará o escritor contemporâneo de mímico. Mas já Benjamin acreditava também que a mais antiga das imitações tinha como única matéria o corpo do imitado; por isso, a seu ver, a dança e a linguagem, o gesto do corpo e os lábios, são as manifestações primordiais da mimese. No entanto, o mímico apenas aparentemente imita, porque, na mimese, há sempre uma polaridade sobre a qual pivotam as duas caras da beleza artística: a aparência e o jogo. Uma é o esquema mais abstrato, mas por isso mesmo, também o mais consistente de todos os

tros, en arte, las cosas tienen también su alma). Alonso no es un técnico, puesto que no consigue dar volúmenes, (salvo los que reproduce al final del catálogo), y su perspectiva aérea es casi nula, siendo siempre arbitraria la distribución de la luz." MARTINEZ FERRER, Horacio. La pintura de Juan C. Alonso. Martín Fierro, a. 2, n. 14-15, jan. 1925, p. 9.

${ }^{30}$ Jorge Barón Biza, analisando as caricaturas rurais de Molina Campos, levanta uma hipótese válida também para Alonso. Argumenta que essa linha de figuração tem características próprias: "va montada sobre algún elemento institucional (empresa, organización política, estructura ideológica), se desarrolla sobre su propia repetición, sin tolerar casi cambios, y se dirige a un público más amplio que el de las galerías. Cuando prende, la relación y la fidelidad de este público son un fenómeno clave si se busca un camino para que el arte tenga amplia repercusión. BARON BIZA, Jorge. Molina Campos. Caricaturas de la Pampa. Por dentro todo está permitido: reseñas, retratos y ensayos. Ed. Martín Albornoz. Buenos Aires, Caja Negra, 2010, p. 83.

${ }^{31}$ MALLARMÉ, Stéphane. Crayonné au théâtre. In: Oeuvres complètes. v. II. Paris: Gallimard, 2003, p. 178-179. 
procedimentos mágicos da técnica; o outro, enfim, configura o reservatório inesgotável de todos os recursos experimentais da técnica. Já o dissemos: fora do trabalho do mímico, não existe nenhuma obra que não seja simultaneamente configuradora e criadora, ao mesmo tempo. O mímico é um siringo.

Cabe lembrar, a propósito, que o autor de Vida das formas, Henri Focillon, guardava, em seu arquivo, a foto de um acrobata, oscilando sobre a pista iluminada de um circo. Sua própria mão intitulou a instantânea: "La dialectique". Da mesma forma, o número inaugural de Plus Ultra explicita o contrato dessa vida vicária das formas sociais, que recolhemos no arquivo imagético do modernismo (imagem 9). Os elevados personagens da transatlantic society não duvidam em posar como saltimbancos, mímicos, travestis ou simples histriões. Sabiam que entre eles e suas imagens se instalaria uma diferença insuperável, mesmo quando se apoiassem na técnica testada (como a do teleóptico apresentado na Plus Ultra, n. 1), ou a radiografia (cuja única vítima, além do mais, será o sujeito a quem um feixe de luz, em total imperícia, atravessa-lhe as carnes). Curiosamente, essa primeira vítima da disseminação (de textos e imagens) se chamava Menard (ver Plus Ultra, n. 6).

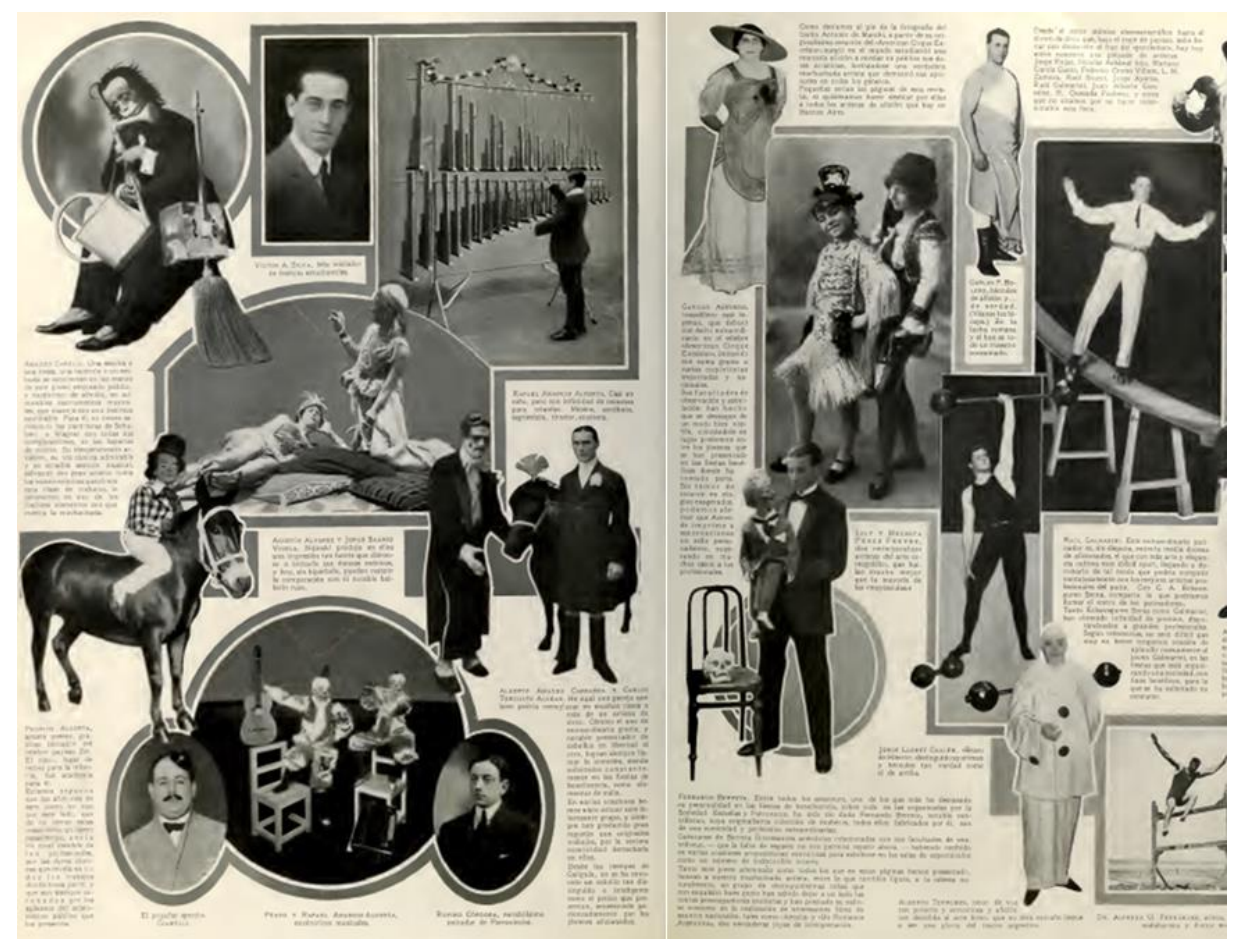

IMAGEM 9 - LA MUCHACHADA ARTISTA

"Plus Ultra", Buenos Aires, Año I, № 1, mar. 1916 
Ler Rubén Darío através do arquivo é ativar o princípio de poema do poema do qual falava Schlegel. Descomposta e recomposta a série da tradição, em outras palavras, quebradas as pontes entre um poema e os outros poemas, entre os poemas e as imagens, e inclusive entre elas próprias entre si, porque cada imagem pode ser, não apenas indício de outra imagem, mas também a escolta, o escólio, de um poema, só nos resta remontá-los a eles todos, simultaneamente embaralhados, para com eles produzir novas descargas esclarecedoras. Por um lado, o poema, conjunto autônomo, fechado em si próprio, revela-se uma construção heterogênea, mas também um bloco compacto de rechaço ao semelhante e trivial. Mas, ao mesmo tempo, o poema tem a leveza do gesto incipiente e inaugural de uma festa cívica, tal como um cerimonial de comunidade. Por um lado, a vida por vir se concentra em um sólido poema modernista; mas, por outro, essa mesma vida se dinamiza no design de um espaço comum transfigurado.

Diríamos, por isso, que há, no arquivo, um evidente afastamento entre textos, imagens e povo, que nos definem, simultaneamente, aos textos e às imagens, como separações do que se pode dizer e do que se pode ver. Portanto, a leitura arquivística, a arquifilologia, propõe o deslocamento entre essas separações, misturadas e sobrepostas, aproximando o distante pelo mesmo recurso da separação. Por essa via conclui, em suma, que é reconfigurando (as lilases e as rosas de cera, as maçãs e as peras de mármore pintado, as uvas de cristal) que se cria uma leitura, tal como uma natureza morta. Imitando o mímico. 